\title{
An Exercise in Police Co-operation? The Origins of the Conference of Australian Police Commissioners
}

\author{
Mark Finnane, Griffith University* \\ John Myrtle, Griffith University*
}

\begin{abstract}
Research in the last two decades on police co-operation has focussed on international co-operation and the policing challenges encountered on the path to a common Europe. Much less attention has been directed at the historical challenges of police co-operation within the boundaries of nationstates with multiple police agencies. In this article we examine the origins of an institutional approach to the problems of policing within a federation. In Australia the police commissioners of the various jurisdictions have been convening in a national forum for more than a century. It is shown that the Conference had its origins in late nineteenth century developments in criminal identification technologies such as Bertillonage and fingerprinting. But in the new constitutional and political context of a Federation without a federal police force, the State police commissioners sought to address a range of policing and criminal justice priorities in their foundation conference. Taking account of the differences between domestic and international policing co-operation, it is nevertheless argued in conclusion that factors such as the bureaucratization of polie forces, their
\end{abstract}


particular constitutional and political conditions, and their shared interests in crime fighting and prevention drove this exercise in institutional co-operation.

* Mark Finnane, ARC Australian Professorial Fellow, ARC Centre of Excellence in Policing and Security, Griffith University; John Myrtle, Associate Investigator, ARC Centre of Excellence in Policing and Security, Griffith University. Research for this article has been supported by the Australian Research Council (DP0771492) and Griffith University. We are grateful to the Conference of Australian Police Commissioners for granting permission to consult their archives. Address for correspondence: m.finnane@griffith.edu.au 


\title{
An Exercise in Police Co-operation? The Origins of the Conference of Australian Police
}

\author{
Commissioners
}

\section{Introduction}

Research in the last two decades on police co-operation has focussed on two domains international co-operation and its connections to transnational policing; and the processes and challenges encountered on the path to a common Europe. ${ }^{1}$ Much less attention has historically been directed at the challenges of police co-operation in federations or within the boundaries of nationstates with multiple police agencies. Yet police co-operation and the harmonization of laws are perennial issues in federations as much as in regional and international domains. In this article we examine the origins of an institutional approach to the problems of policing within a federation. In Australia the police commissioners of the various jurisdictions have been convening in a national forum for more than a century. The genesis and context of their first meeting for the advancement of police co-operation is the subject of this article.

In sum, we argue that the historical evidence from Australia suggests that the emergence of police co-operation within national boundaries is likely to replicate the patterns observed in the development of international police co-operation across the late nineteenth and early twentieth

\footnotetext{
${ }^{1}$ J.W.E. Sheptycki, In Search of Transnational Policing: Towards Sociology of Global Policing. Advances in criminology (Aldershot, UK, 2003); Peter Andreas and Ethan Nadelmann, Policing the Globe: Criminalization and Crime Control in International Relations (New York, 2006); Malcolm Anderson, Policing the World: Interpol and the Politics of International Police Co-operation (Oxford, 1989); Mathieu Deflem, Policing World Society: Historical Foundations of International Police Co-operation. Clarendon studies in criminology (Oxford, 2002); Mark Mazower (ed), The Policing of Politics in the Twentieth Century: Historical Perspectives (Providence, RI, USA, 1997); Fredric Scott Zuckerman, The Tsarist Secret Police abroad : policing Europe in a modernising world (Basingstoke, England: Palgrave Macmillan, 2003).
} 
centuries. The history of police co-operation of the kind that has supported the development of Interpol and Europol is now well understood in its general outlines. ${ }^{2}$ Deflem in particular has highlighted the conditions necessary to the development of cooperation. In a Weberian argument critical of state-centred or economistic accounts of the development of international police cooperation, he stresses the importance of bureaucratic development of police forces as autonomous organisations that became capable of policing actions independent of state direction. At the same time his detailed study of these developments in the nineteenth and twentieth centuries leads him to insist on the vulnerability of international police cooperation in the face of paramount national interest. These authors and others have also highlighted the importance of cooperation as a response to political security threats. ${ }^{3}$

What is less developed in the literature on the growth of police institutions is an understanding of the mechanisms, objectives and resistances to police co-operation at levels within nation-states. How do these theses from the historical study of international police cooperation apply in understanding police cooperation at the sub-nation-state level? After all, there are very many nation-states which are federations or have policing arrangements which distribute policing functions across a number of jurisdictional levels. In this regard the long history of organisations and mechanisms that have sustained police communication and co-operation since the beginning of the twentieth century deserves investigation and reconstruction.

Within states, rather than between them, the problems of police co-operation have historically presented themselves very differently according to the sovereign and constitutional arrangements

\footnotetext{
${ }^{2}$ In addition to references in fn.1 above, see Hsi-Huey Liang, The Rise of Modern Police and the European State System from Metternich to the Second World War, (Cambridge, 1992)

${ }^{3}$ Clive Emsley, 'Political Police and the European Nation-State in the Nineteenth Century', and Cyrille Fijnaut, "The International Police Commission”, both in Mark Mazower (ed), The Policing of Politics in the Twentieth Century; Richard Bach Jensen, "The International Anti-Anarchist Conference of 1898 and the Origins of Interpol”, Journal of Contemporary History, vol. 16, no. 2 (1981), pp.323-347
} 
(nation-states, federated states, unitary states with multiple local police forces). To highlight the distinctiveness of the Australian story that is the focus of this article we need to recognize the political and constitutional context of federation of the colonies, achieved in the establishment of the Commonwealth of Australia in 1901. In the domain of law and justice the constitution created (and to a large degree maintains to this day) a divided responsibility. Colonies became States, and the criminal laws of the colonies continued as the criminal laws of States. In the foundation years of the federation there was only very limited Commonwealth (ie national) criminal jurisdiction, limited to the federal territories (though this included from 1911 the Northern Territory, after its transfer from the South Australian jurisdiction). The enactment in 1914 of the Commonwealth Crimes Act, together with the impact of war, added great powers and many new offences in the Commonwealth jurisdiction. Yet for many years the policing responsibility for even these Commonwealth powers rested with the State police forces.

The creation of a unified nation-state did not therefore entail the replacement of State criminal jurisdiction and related policing institutions. On the other hand federation catalysed the need for cooperation and improved communication in the management of criminal justice. One early expression of the need to address these objectives was the event we examine in this article, the first Conference of the Australian Police Commissioners. In a meeting largely lost to history, the Commissioners of the six Australian States first gathered for a formal meeting in October 1903. ${ }^{4}$ As we will see, their agenda was well developed and their deliberations substantial. In its origins the Australian Conference appears very distinctive in its time. While there had been 'clubs' of chief constables in Britain going back to the 1850s, their role and function was very limited before the

\footnotetext{
${ }^{4}$ See: Robert Clyne, Colonial Blue: a History of the South Australian Police Force, 1836-1916 (Netley, SA, 1987), p. 226; Clyne's note is a rare acknowledgement of the existence of the conference: 'an important development in the history of Australian policing, providing police chiefs with a forum to discuss a wide range of subjects of mutual interest and to develop closer co-operation.'
} 
First World War. In Reiner's view, their basic business 'was scarcely more than being an “officers' club” performing primarily social and welfare functions for members’ ${ }^{5}$ The 1903 Conference was quite other than that, having before it an agenda of specific policing issues that reflected contemporary priorities and anxieties. Similarly the Conference, in the scope of its ministerial endorsements, was far more institutionalized in the formal apparatus of government than bodies like the International Association of Chiefs of Police (IACP) which had been formed in the United States in 1893, later adding Canadian and eventually numerous other affiliates. The IACP had a powerful agenda of professionalization, lobbying for changing police standards and the introduction of preferred policing technologies. ${ }^{6}$ The like Canadian entity, the Chief Constables Association of Canada (CCAC), was founded in 1905, had similar ambitions to the IACP and developed over the long term a very public lobbying role. ${ }^{7}$ As we will see, the Australian Conference was both more and less than these - more by virtue of its bureaucratic mandate, less by the constraints that this characteristic imposed.

Nevertheless, for reasons which remain unclear the seeds sown in 1903 proved slow to grow. It was not until the national emergency of war that the Commissioners gathered again in 1917, this time prompted by British imperial as well as national demands. The initiative of 1917 was again followed by a gap until 1921 when a re-convened conference established the Conference as an annual event. Interrupted only by the years of the Great Depression (1930-1936), the Conference has met annually since that time. In more recent decades the Conference has been supported by a Secretariat and has developed a capacity to direct collective initiatives under the umbrella of inter-

\footnotetext{
${ }^{5}$ Robert Reiner, Chief Constables: Bobbies, Bosses, or Bureaucrats? (Oxford, 1991), p. 362.

${ }^{6}$ R. Dean Smith, 'The International Association of Chiefs of Police - Its Origins, History, Organisation and Work', Police Studies: The International Review of Police Development, vol. 1 (1978), p. 25; Simon A. Cole, Suspect Identities: A History of Fingerprinting and Criminal Identification (Cambridge, MA, 2001), pp. 149, 220, 241-246

${ }^{7}$ Greg Marquis, 'Canadian Police Chiefs and Law Reform - the Historical-Perspective', Canadian Journal of Criminology-Revue Canadienne De Criminologie vol. 33, no. 3-4 (October, 1991), pp. 385-406; Greg Marquis, Policing Canada's Century: A History of the Canadian Association of Chiefs of Police, (Toronto, 1993)
} 
governmental co-operation. In its earliest years the Conference members were the State

Commissioners. As Commonwealth justice and policing agencies developed in the inter-war years the Commonwealth Police Commissioner gradually joined the exercise and from the late 1930s the New Zealand Commissioner also attended. The expansion of Australian's colonial and Pacific remit enlarged the fold in the 1960s to include police leaders from Papua New Guinea and many Pacific states in the region. The trend continues - in the wake of the development of the Australian Federal Police International Deployment Group since 2000, it is now common for police leaders from South-East Asia to be invited to the Conference.

The agenda of the Conference has expanded enormously since 1903 when, as we discuss below, there were but 11 items. The meetings were always longer than a day and from the 1940s lasted a week, with agenda covering personnel, crime, operational policing, national security and many other key policing issues. By the 1940s the institutional complexity and the scope of policing had differentiated so many functions and agencies within policing that it made sense to initiate interjurisdictional meetings of specialized units such as detectives in criminal investigation units. ${ }^{8}$ Such lower level meetings generated expert advice as well as agenda items of their own passed up through the police bureaucracies to arrive at the Conference of Police Commissioners. Those later developments however are not the remit of this article. Nevertheless, the scale and significance of the longer history can be apprehended through appreciating the origins and context of the small beginnings in 1903.

\section{Initiators}

\footnotetext{
${ }^{8}$ The Proceedings of the Conference (which are the source for this summary of the Conference agenda) remain unpublished. By permission we have accessed records held in the Library of the Australian Federal Police, and in the Office of the Chief Commissioner, Victoria Police. Other sources for the Conference agenda and its policy and practical impacts may be found in the various national and State archives, as used in this article.
} 
As much as the first Conference of Australian Police Commissioners was an event of the early federation years its genesis was an inter-State rather than Commonwealth initiative. The immediate stimulus was an approach from Western Australia’s Commissioner to the Victorian Chief Commissioner in July 1903: 'I should be very pleased if you would kindly favor me with your views regarding the advisability of holding a conference of the Heads of the Police Forces in the various states. ... Personally, I have held the opinion for some time that such a conference would prove of much utility. ${ }^{9}$

Frederick Hare, Commissioner of Police in Western Australia since 1900 was (it is said) 'not among the most highly regarded of Police commissioners' ${ }^{10}$ But in this initiative he was forwardlooking, and sensitive to his times. By 1903 each of the police commissioners had different reasons for wanting to meet with other police chiefs. Hare's own suggestions, among the 'many subjects [that] might engage the attention of the conference', included an examination of the practicality of adopting a uniform system of working in the police forces of the different states; an improved method of police surveillance with regard to criminals moving from one state to another; the periodic interchange of detectives; and examination of the various Police Acts and licensing laws in force in different states. ${ }^{11}$

The recipient of Frederick Hare’s letter, Thomas O’Callaghan, had been appointed Chief Commissioner of the Victoria Police only the previous year. Born in 1845, he had joined the Detective branch of the Victoria Police Force in 1867. His early police career was marked by controversy but, as Chief Commissioner, O’Callaghan was responsible for the introduction of

\footnotetext{
${ }^{9}$ F Hare to T O’Callaghan, 1 July 1903, VPRS 3992 1903, Chief Secretary's Dept, Public Record Office of Victoria (hereafter VPRO). A record of the correspondence may also be found in the State Records, Western Australia: Acc 430, AN 5/1, 2147/03 - we thank an anonymous reviewer for this advice.

${ }^{10}$ Peter Conole, Protect \& Serve: a History of Policing in Western Australia (Perth, WA, 2002), p.133

${ }^{11}$ F Hare to T O’Callaghan, 1 July 1903, VPRS 3992 1903, VPRO
} 
fingerprinting, and promoted the formal training of police. ${ }^{12}$ O’Callaghan welcomed Hare’s letter, commending the suggestion to his administrative head, the Undersecretary of the Chief Secretary's Department: 'I think Captain Hare’s suggestion a good one. The meeting might be arranged for Monday $19^{\text {th }}$ October in Melbourne. If Mr Parry-Okeden [of Queensland] approves he might send this on to Mr Fosbery [of New South Wales] for an expression of his opinion. ${ }^{13}$

As the warm recommendation of O’Callaghan's memo implied, Hare's suggestion was not the first time such a proposal had been raised. Australian policing conditions were conducive to such initiatives, although it was the momentum of federation that catalysed the development of a formal mechanism for advancing co-operation in law enforcement. Since the mid nineteenth-century the different Australian colonies had embraced a centralised police model with each police force headed by a commissioner who answered to a self-governing colonial administration. This model had applied in all of the mainland jurisdictions, the only exception being Tasmania where a centralised model was not introduced until the end of the century. ${ }^{14}$ Strong central control of police forces, which ranged over territorial jurisdictions larger than many European states, facilitated the development of specialised services in fields such as criminal investigation and licensing, utilising photography, fingerprinting, communications, transport and other new technology $\cdot{ }^{15}$ By the late nineteenth century Australian criminal justice administrators were adapting some of the new technological and administrative innovations for their own purposes. In 1888 NSW Comptroller General of Prisons Maclean learned in Paris of the French uses of the recently introduced Bertillon

\footnotetext{
${ }^{12}$ Gary Presland, “Thomas O’Callaghan: Police Commissioner and Historian”, Victorian Historical Journal, Vol.74 (2003), pp.155-166

${ }^{13}$ T O’Callaghan, note for file, 7 August 1903, VPRS 3992 1903, VPRO

${ }^{14}$ Mark Finnane, Police and government : histories of policing in Australia (Melbourne, 1994); Stefan Petrow, “"Economy, Efficiency and Impartiality”: Police Centralisation in Nineteenth Century Tasmania', Australian and New Zealand Journal of Criminology, Vol.31(1998), pp.242-266

${ }^{15}$ Dean Wilson, The Beat: Policing a Victorian City (Beaconsfield, Vic, 2006); Robert Haldane, The People's Force: $a$ History of the Victoria Police (Carlton, Vic, 1986); W. Ross Johnston, The Long Blue Line: A History of the Queensland Police (Bowen Hills, Qld, 1992)
} 
system of prisoner identification, involving anthropometric measurements, that was later replaced by fingerprinting. In the mid-1890s the NSW government attempted to gather support for the general adoption of 'bertillonage' in the Australian colonies, for the express purpose of establishing a 'uniform system for the registration and identification of habitual criminals'. The proposal was recognized as one involving 'Federal interests' and was promoted as such by the NSW government. The system was however expensive in administration compared to photographic documentation, a difficulty standing in the face of its general adoption in $1895 .{ }^{16}$ Irrespective of this outcome, it is the self-consciously 'federal' reference of such policy discussions that suggests why postFederation initiatives in police-co-operation already had a context of inter-governmental consideration.

It was indeed the moment of federation, namely the establishment of the Commonwealth of Australia in January 1901, that prompted the next significant development in police co-operation. William Parry-Okeden had been appointed Queensland Commissioner of Police in July 1895, from outside the police service. ${ }^{17}$ He had been a long-standing head of the Colonial Secretary's Department, the core of Queensland public administration, with oversight of the police administration. Under Parry-Okeden Queensland's police promoted scientific innovations such as photographic and fingerprint methods, building on the State's record of innovation in identification technologies. It was in Queensland (possibly under the stimulus of French penal innovation that proposed to transfer recidivists to the penal colony on New Caledonia) that police had developed photographic identification of offenders convicted but released under probation legislation enacted

\footnotetext{
${ }^{16}$ Correspondence, COL/A793 [7661], Queensland State Archives (hereafter QSA)

${ }^{17}$ W Ross Johnston, The Long Blue Line: A History of the Queensland Police (Bowen Hills, Qld, 1992); Michael D de B Collins Persse, "Parry-Okeden, William Edward (1840 - 1926) [biographical entry]". Australian Dictionary of Biography, Vol.11 (Melbourne, 1988), pp.147-148
} 
in $1886 .{ }^{18}$ And it was certainly another kind of interaction with the penal apparatus of the French empire that prompted Parry-Okeden into discussion with his fellow commissioners in 1901 about the new technologies of identification that were being developed in Europe.

In 1901 Parry-Okeden visited Sydney, possibly as part of his State’s delegation for the proclamation of the Commonwealth. He used the opportunity to meet with the penal reformer Captain Frederick Neitenstein, Comptroller-General of Prisons in New South Wales, as well as the less dynamic head of police in New South Wales, Inspector-General Edmund Fosbery. During the Sydney visit he also appears to have met H M Chomley, O’Callaghan’s predecessor as Victorian Chief Commissioner. ${ }^{19}$

Parry-Okeden's meeting with Fosbery was more than a courtesy call. Shortly after the meeting, and while he was still in Sydney, Parry-Okeden wrote to Fosbery recording details of the extensive subjects covered by their meeting and matters that still required clarification. The most important issue for the Queensland Commissioner was an appropriate system of identification of criminals. New South Wales favoured the Bertillon system ${ }^{20}$. Queensland authorities had knowledge of the system but they had adopted 'a modification of the more scientific methods of identification of criminals’. Queensland's awareness of the Bertillon system had arisen from the visits to Queensland of French military warders 'rendered necessary by the frequent arrests in [Queensland] of French escapees from New Caledonia’. Indeed French penal authorities had trained Queensland detectives in their system of identification. In the Queensland commissioner's view, it 'would not

\footnotetext{
${ }^{18}$ Stephen White, “Howard Vincent and the development of probation in Australia, New Zealand and United Kingdom”, Historical Studies, Vol.18 (1979), pp.598-617; Mark Finnane, Punishment in Australian Society, (Melbourne, 1997), pp.90-2

${ }^{19}$ Queensland. Report of the Commissioner of Police for the Year 1902: 5; Parry-Okeden to O’Callaghan, 31 Oct 1902, VPRS 3992 1903, VPRO

${ }^{20}$ John Ramsland, With just but relentless discipline: a social history of corrective services in New South Wales. (Kenthurst NSW, 1996), pp. 168-169.
} 
be difficult to arrange with the French Government to have the [Bertillon] system properly taught in the States, if the various governments will facilitate its installation.' What was standing in the way of such a development was 'the want of unity ... and the impossibility without interstate action, of securing proper teaching.' Parry-Okeden's memorandum indicated that he would be travelling on to Melbourne and Adelaide and would be discussing the issue of classification of criminals with authorities in those places. ${ }^{21}$

The importance of Parry-Okeden’s January 1901 memorandum lay not in its reflections on the utility or otherwise of the Bertillon system of classification (which was rapidly being overtaken by developments in fingerprinting technology) but rather that the Queensland commissioner was looking beyond his own State for the means of advancing police effectiveness in criminal justice administration. The proximity of New Caledonia had long necessitated a degree of co-operation between Queensland and other Australian colonies in pursuit of escapees - but the need for such co-operation was not limited to the international sphere. Inter-colonial movement of offenders and suspects had already tried the patience of colonial police administrations and their law advisers. ${ }^{22}$ Federation enlivened the possibility of inter-state movement of fugitives in ways that were yet to be tested. So Parry-Okeden's memorandum canvassed issues such as the pursuit of fugitive offenders under the legal system of the new federation; the regular interchange of detectives (already suggested by the Western Australian Premier); together with a long list of queries about police practice in New South Wales, covering areas from communications and beat work to the procedures for investigating police misconduct. ${ }^{23}$

\footnotetext{
21 'Memorandum for Mr Fosbery', 14 January 1901, A44776, QSA.

${ }^{22}$ In the 1880s Queensland police constables serving on the border with South Australia were sworn into the South Australian Police but by 1890 there were doubts whether such practices were ultra vires: see Copy of Solicitor General's Memo (Queensland), 29 Nov 1890, in A/45400, QSA. We thank Jonathan Richards for this reference. 23 'Memorandum for Mr Fosbery', 14 January 1901, A44776, QSA.
} 
While there was no immediate outcome of the Sydney meetings in 1901, in October 1902 ParryOkeden was again agitating the case for inter-state co-operation. Writing to the new Victorian Chief Commissioner O'Callaghan, the Queensland Commissioner set out the arguments: 'Now is the time to tackle a subject that I'm sure you will be as interested in as I am ... the great good to the Commonwealth that would be secured by the adoption by the states [sic] police of uniform systems of identification and classification of criminals. ... What is wanted is a conference of heads of Police of each state, say in Melbourne or Sydney, and the adoption of the best features of the systems now working in each state and by dovetailing them with such modifications of the more scientific \& elaborate systems in use in other countries making up a good \& effective whole. The finger marks are the great \& easily worked sheet anchor. I could, I think get my [Government] take it up if you join me. ${ }^{24}$ The Queensland prisons administration had already pressed on ParryOkeden the virtues of the fingerprint system. This was in the earliest stages of its quite rapid development and adoption, first in India and then in Britain. ${ }^{25}$ The introduction of new systems of identification was seen to be an important part of the response of police and prisons departments to the increasing mobility of population between and within states and jurisdictions.

Thus by the time Hare wrote to O'Callaghan in July 1903 pressing for a meeting of the 'Heads of Police Forces’, much preliminary discussion had already taken place. Following Parry-Okeden’s earlier approaches, O'Callaghan already had in hand his government's support for such an initiative and so invitations were dispatched. Predictably, the response from Queensland was enthusiastic.

Most other State police chiefs proved supportive. Tasmanian Police Commissioner, George

\footnotetext{
${ }^{24}$ W Parry-Okeden to T O’Callaghan, 31 October 1902, VPRS 3992 1903, VPRO

${ }^{25}$ Richard S Hill, The Iron Hand in the Velvet Glove: The Modernisation of Policing in New Zealand (Palmerston North, NZ), pp.167-174; Kristin Ruggiero, "Fingerprinting and the Argentine Plan for Universal Identification in the Late Nineteenth and Early Twentieth Centuries", in Jane Caplan and John C Torpey (ed) Documenting Individual Identity: The Development of State Practices in the Modern World (Princeton, NJ, 2001), pp.184-196; Mark Finnane, Police and Government: Histories of Policing in Australia (Melbourne, 1994), pp.80-2; Ramsland, With just but relentless discipline, pp. 168-171.
} 
Richardson (commissioner from 1899-1906) knew of 'no burning question to be discussed, but a general interchange of views will no doubt be beneficial to the service, as well as individually interesting'. In any case he proved the value of an agenda to consider inter-state cooperation when he proposed discussion of the execution of warrants in extradition cases; at the time no State police could arrest for a crime committed in another State except on the original warrant. ${ }^{26}$ The spirit of co-operation extended to an invitation across the Tasman, but in September the New Zealand Premier Richard Seddon declined the invitation to participate, indicating in a telegram to the Victorian Premier that his Chief Commissioner had only recently arrived in the Colony and had not yet had time to travel through the Colony or become acquainted with his officers. ${ }^{27}$ Only in New South Wales was the police chief decidedly negative. ${ }^{28}$ Fosbery's lack of interest probably reflected the world weariness of a bureaucrat who had been in charge of the police nearly three decades, since 1874, and was on the verge of retirement. There was of course every reason for New South Wales, the largest Australian State, to be involved. Fosbery’s 1902 annual report had already acknowledged the value of the assistance of police in other states, particularly in tracing absconding criminals ${ }^{29}$. After Fosbery declared the lack of necessity for a conference and so advised his government, Parry-Okeden was not shy in telling O’Callaghan that he could not understand such an attitude: 'I think it is of the greatest moment that Police heads should meet and discuss \& settle a vast number of matters relating to Police work that cannot be dealt with by correspondence. ${ }^{30}$ From South Australia, Commissioner LG Madley (1896-1909) suggested the conference should go ahead without Fosbery, but added that the Victorian Premier might write to

\footnotetext{
${ }^{26}$ G Richardson to T O’Callaghan, 14 August 1903, VPRS 39921903 VPRO

${ }^{27}$ R J Seddon to W H Irvine, 20 September 1903, VPRS 3992 1903, VPRO

${ }^{28}$ E Fosbery to T O’Callaghan, 19 August 1903, VPRS 3992 1903, VPRO

${ }^{29}$ New South Wales. Police Department, Report for the Year 1902: 4

${ }^{30}$ W Parry-Okeden to T O’Callaghan,22 August and 6 September 1903, VPRS 3992 1903, VPRO
} 
'the Sydney government [the] desirableness of Sydney being represented ${ }^{31}$. Western Australia’s Premier, Walter James, was a strong supporter, though inaccurate in his claim that the conference had 'been unanimously agreed to by the Commissioners of Police of the rest of the Commonwealth and New Zealand. ${ }^{32}$

Against this background, New South Wales eventually fell into line. In the end it was represented by Edmund Fosbery's deputy, Thomas Garvin, who was to succeed Fosbery as Inspector-General of Police in New South Wales. But Garvin proved a reluctant participant, warning O’Callaghan at the outset that 'we should be able to get through all business in one day. ${ }^{33}$ Given the travel commitment required from other commissioners located at a greater distance from Melbourne, it was unrealistic to expect that any such conference would be of short duration. In the event Garvin did not attend the entire conference and his comments attached to the final report indicate that he was not present during key agenda sessions.

The very establishment of the conference was a significant moment in post-federation governance. More than most other areas of domestic policy, policing interests were likely to involve crossjurisdictional issues. Other domains of government in the 1900s, such as hospitals or education, were jealously guarded provinces of State concern and it would be many years before demands would be made for an inter-State approach to such policy arenas - most notably in the development of Commonwealth public health policy some two decades later. ${ }^{34}$ Some related functions of criminal justice relevance, such as the movement of people and goods at the Australian borders

\footnotetext{
${ }^{31}$ Madley to O’Callaghan, 9 September 1903, VPRS 39921903 , VPRO

${ }^{32}$ W James to W H Irvine, 20 August 1903, VPRO; F Hare to T O’Callaghan, 10 September 1903, VPRS 3992 1903, VPRO

${ }^{33}$ T Garvin to T O’Callaghan, 12 October 1903, VPRS 3992 1903, VPRO

${ }^{34}$ Michael Roe, "The Establishment of the Australian Department of Health”, Historical Studies Australia and New Zealand, No. 67 (1976), pp. 176-192
} 
were constitutionally determined to be the business of the national government from $1901 .{ }^{35}$ But policing business remained the responsibility of the post-federation States. When the Australian Prime Minister received in August 1903 a letter from New Zealand inquiring of the potential for employment in the establishment of a criminal identification bureau, he replied to the writer that 'as the Police administration of Australia is in the hands of the State Governments, there is hardly likely to be any opportunity of the Federal Government availing itself of his services’. ${ }^{36}$ In those areas where Commonwealth agencies required police assistance, arrangements were made for the secondment of State police. ${ }^{37}$ Within this context we can see that the late colonial discussion of the problem of inter-jurisdiction mobility of 'habitual criminals' was a vital factor informing the proposal for police co-operation. More generally, we suggest, the familiarity of criminal justice administrators with the international issues of co-operation and innovation, associated especially with people movement and questions of identification, rendered police chiefs conscious of the challenges involved in a world of borders and the increasing capacity to cross as well as monitor them. Such factors shaped the emergence of the first Conference of Police Commissioners, and are reflected in its agenda and discussions, to which we now turn.

\section{Agendas}

The preparation of the Conference agenda lay in the hands of the Victorian Chief Commissioner. There was little to surprise in its items, given the background we have already considered. The identification of criminals and the tracking of their movements was the dominant issue, perhaps given added weight by the Prime Minister's missive on the subject of identification bureaux and the

\footnotetext{
${ }^{35}$ David Day, Contraband \& Controversy: The Customs History of Australia from 1901 (Canberra, 1996)

${ }^{36}$ Barton (PM) to Premier of Qld, 19 Aug 1903, A44776, QSA.

${ }^{37}$ See eg Argus 22 October 1903: 4 - 'A federal police force is not to be created at present. The Postmaster-General has decided that the detectives lent to his department by the state Police department need not become officers of his department.'
} 
use of fingerprinting by police and prisons departments. ${ }^{38}$ By September O’Callaghan's advice to the commissioners was that the conference would cover subjects including also the dissemination of crime reports; the adoption of uniform systems for crime statistics and criminal identification, and the interchange of police between jurisdictions. ${ }^{39}$

The commissioners convened in Melbourne in late October 1903, meeting in the offices of the Victorian Chief Secretary's Department. To a degree surprising today, the proceedings of the conference were widely publicized, with newspapers from both Melbourne and Sydney providing short reports on progress over the 9 days of proceedings. On the opening day, Thursday 22 October, The Age reported that the "chief subjects ventilated ... were the extradition of offenders ... and the identification and classification of criminals, a subject which is at present receiving increasing attention in Australia at the hands of those whose business is the detection and apprehension of offenders. ${ }^{40}$ A report in the Argus elaborated - the commissioners were looking for a system of uniform identification, and probably not the Bertillon method, 'which is regarded as being too cumbrous and expensive for general use'. ${ }^{41}$ On Friday the commissioners 'sat for an hour and a half ... to discuss the interchange of police between the various States’. The objects of such interchange were to 'enlarge the knowledge of police officers in respect to the criminal classes of Australia, and enable them to gain much valuable experience both in criminal methods and organisations, and in the matter of departmental discipline and administration'. The conference was reported to welcome the proposal. ${ }^{42}$ On the following Monday morning, before O’Callaghan introduced the inter-State visitors to the Premier, Superintendent Sharp of the Victorian Criminal

\footnotetext{
${ }^{38}$ Copies of outward correspondence with State Premiers dated between 10 January 1903 and 1 May 1903, National Archives of Australia, A33 (A33/1), 1

${ }^{39}$ T O’Callaghan to Under Secretary, Chief Secretary’s Dept, 14 September 1903, VPRS 3992 1903, VPRO

40 The Age, 23 October 1903: 4

${ }^{41}$ Argus, 23 October 1903: 5. The Sydney Morning Herald reproduced this article on the same day.

${ }^{42}$ The Age, 26 October 1903: 4
} 
Investigation department 'read a paper on Police Organisation'. Sharp spoke of the development of a 'Model police force', and 'the need of a higher educational standard' ${ }^{43}$

The conference proceedings were not limited to the commissioners talking among themselves. O’Callaghan had perhaps a more local (ie Melbourne) agenda in mind when he evidently briefed the conservative Argus newspaper a fortnight earlier on his aim of getting the 'view of all the visiting members on all questions relating to criminology, commencing with neglected children’. Only recently, he had drawn media attention through his comments on 'methods of dealing with "human tigers", ${ }^{44}$ On the Monday afternoon the commissioners visited Melbourne’s Pentridge Prison. The following day they were addressed by Captain W. Davies, the departmental secretary of the Victorian Neglected Children's Department. Dealing with the problems of neglected children, Davies emphasized the importance of co-operation between the police and education departments in managing truancy. He then added his own recommendations for law reform to raise the age of 'youthful offenders' from 17 to 18 to enable them to be sent to reformatories rather than prisons. Davies also suggested that police could be more active in taking full advantage of the provisions of the Neglected Children's Act. ${ }^{45}$ Alone among the newspapers, The Age (Melbourne's liberal and progressive broadsheet) saw fit to report Davies’ remarks. Neither did Davies’ comments seem to inspire the commissioners into adding to their concerns - their final report omitted any mention of policing of children and juveniles. ${ }^{46}$

The conference continued throughout the second week, concluding on Saturday 31 October. In the final sessions the commissioners 'discussed the draft of the recommendations to be made to the

\footnotetext{
${ }^{43}$ The Age, 27 October 1903: 4

${ }^{44}$ Argus, 13 October 1903: 5.

${ }^{45}$ The Age, 28 October 1903: 6

${ }^{46}$ Davies had been invited to present by Victoria’s Chief Commissioner O’Callaghan, evidently with
} 
various Governments, and also dealt with a number of matters in which the commissioners will be able to adopt uniform action on their own responsibility. ${ }^{47}$ O’Callaghan proved mindful of the need to capture the potential of the event, committing himself to the production of a draft report which remains the principal record of the proceedings.

O’Callaghan’s 15 page draft, 'Report of Police Conference Held at Melbourne on Thursday $22^{\text {nd }}$ October, and Following Days’, was subsequently forwarded to the participants for their comment and approval, a process which took some months. The range of items on this historic record amplified the topics on the original agenda, but shows the close attention to issues that were characteristically challenging to policing across borders. The key headings followed:

1. Extradition of fugitive offenders

2. Identification and classification of criminals

3. Arrival and departure of criminals

4. Dissemination of crime reports

5. Uniform system of criminal registration

6. Interchange of police

7. Service of summonses and execution of warrants under Federal Acts

8. Police on borders of States

9. Prostitution

10. Influx of criminals

11. Habitual criminals

Some issues were covered in detail; with others, the report only served to record that the matter had been included as part of the agenda for the conference. In the absence of a formal record of conference proceedings, communication around the finalization of the draft serves as a valuable indicator of senior police thinking on a range of problems connected with policing within and between jurisdictions.

As we have seen, the technologies of Bertillonage and fingerprinting in their connection to problems of criminal identification had stimulated inter-State dialogue even before federation. So it

${ }^{47}$ The Age, 30 October 1903: 4 
was appropriate that on the first day of the conference the commissioners had discussed the identification and classification of criminals. In their report they agreed that 'a common system of photography, personal description and finger prints be adopted in each of the States as an identification and classification of criminals. ... In the absence of a central bureau it [would] be necessary to send copies of all finger prints taken in one State to the authorities in all other States ...'. Photography would be utilised for making copies of the finger prints. It was agreed that the work of photographing, obtaining finger prints and describing criminals should be undertaken by 'the Penal [ie Prisons] Departments' in all of the States. ${ }^{48}$

With the privileges attached to their authority over convicted prisoners, prisons departments had already pioneered systems of registration and identification. Commenting on the report, William Parry-Okeden of Queensland expressed the hope that a Central Bureau be established 'under the Prisons Department. ${ }^{49}$ Prison administrators were early acquainted with the ambitious co-operative agenda adopted by the Australian police commissioners. In his 1903 annual report, Victoria’s Inspector-General of Penal Establishments and Gaols wrote: 'The system of identification by means of finger prints has now been introduced, in addition to the photographs and personal descriptions formerly in use. Uniformity in this regard, in all the States, is likely to be brought about as a result of the recent Police Conference, and there can be no doubt of the advantage this will be in enabling the authorities in any State to trace migratory criminals and check imposition. ${ }^{, 50}$

The extradition of fugitive offenders was largely an issue of the commissioners seeking to adopt a consistent approach in dealing with requests for extradition from other States. The complexity of

\footnotetext{
48 'Report of Police Conference Held at Melbourne on Thursday $22^{\text {nd }}$ October, and Following Days', pp.3-4, (hereafter Report), VPRS 3992 1904, VPRO

${ }^{49}$ W Parry-Okeden to [T O’Callaghan], [Feb 1904], VPRS 3992 1903, VPRO

${ }^{50}$ Victoria. Penal Establishments \& Gaols. Report of the Inspector-General for the Year 1903: 5-6
} 
the problem was indicated in the drift of discussion among the commissioners who proved much preoccupied with controlling the expense incurred in returning offenders to the requesting State. The commissioners were joined in suggesting that the law officers of the States be requested to consider whether chiefs of police had the legal right to refuse to extradite offenders in cases not wholly a matter of public concern. ${ }^{51}$

Extradition overlapped with another contemporary anxiety - the inter-State movement of criminals. Several States had already enacted or contemplated an 'Influx of Criminals Prevention Act'. The commissioners hoped that all would follow, noting that 'the usefulness [of such legislation] in dealing with migratory criminals has been conclusively proven. ${ }^{52}$ This assurance disguised a complexity with the issue arising from the requirements of the Federal legal system. The NSW Influx of Criminals Prevention Act had been signed into law just weeks before the police conference. At that stage Victoria did not have similar legislation but in 1905 Queensland, and in 1909 Tasmania, enacted legislation based on the New South Wales Act. ${ }^{53}$ From an early stage there were doubts concerning the constitutionality of the statutes. In 1912 the High Court declared the New South Wales Act in breach of Section 92 of the Constitution prohibiting restrictions on cross-border movements within the Federation. ${ }^{54}$

In the absence of effective State capacity to stop people movements between them, the kind of cross-border intelligence that was encouraged by inter-State exchange of detectives after 1903 was likely to be all the more valued after the High Court's later decision. Cross-border work of another kind was equally contemplated in 1903 in relation to execution of warrants. Was it 'desirable that

\footnotetext{
${ }^{51}$ Report, pp.2-3

${ }^{52}$ Report, p.7; Mark Finnane, 'The politics of police powers', in Finnane (ed), Policing in Australia Historical Perspectives (Kensington NSW, 1987)

${ }_{53}$ Influx of Criminals Prevention Act 1905 (Qld); Influx of Criminals Prevention Act 1909 (Tas)

${ }^{54} R v$ Smithers [1912] HCA 96; (1912) 16 CLR 99 (20 December 1912) (http://www.austlii.edu.au/au/cases/cth/HCA/1912/96.html).
} 
statutory power be given to the Police of one State to execute warrants in another State’? The commissioners agreed that such a provision would be advantageous in sparsely populated districts 'where police were only to be found on one side of the border line over a very considerable distance.' But this was a matter for legislative action, requiring State governments to harmonise their laws, and the commissioners held the matter over for another time. ${ }^{55}$

While much of the conference was thus devoted to the implications of the new federal arrangements for operational policing, there was an underlying concern with a contemporary preoccupation, the options available to governments in dealing with habitual criminals. The search here was not for answers to inter-jurisdictional problems but for ideas and approaches to issues of common concern. At Melbourne’s Pentridge Prison the commissioners had heard from the Prison Governor, Mr Cody, on the problem of 'inequality of sentences'. ${ }^{56}$ In focusing on 'habitual criminals', the commissioners were dealing with a legacy of nineteenth century penal policies confronted by the challenges of new thinking associated with the rise of criminology. The intensive policing and surveillance regimes that had been associated with British penal innovation around the problem of habitual criminals in the 1860s ( an attempt to manage post-release prisoners to reduce the risk of their re-offending) was now in tension with approaches that sought to individualise the habitual offender by way of indeterminate sentencing to specialised institutions. ${ }^{57}$ The commissioners were divided over the desirable way to proceed, in a matter which is any case was well beyond their remit. The otherwise indifferent NSW delegate, Thomas Garvin, who had not attended this part of the conference, objected that policy on indeterminate sentences and the sentencing of habituals was ‘more a question of Government Policy than Police administration’.

\footnotetext{
${ }^{55}$ Report, p.5

56 The Age, 27 October 1903: 4

${ }^{57}$ S J Stevenson, “The 'Habitual Criminal' in Nineteenth-Century England: Some Observations on the Figures”, in Urban History Yearbook 1986 (Leicester, UK, 1986), pp.37-60; Norval Morris, The habitual criminal (London, 1951)
} 
The fanciful proposals developed by O’Callaghan out of the debates worked towards a penalties scheme that was indeed a legacy of the British habtitual criminals regime. Sentences for offenders appearing consecutively would increase at each appearance until an offender was effectively serving a life sentence. ${ }^{58}$ In a jurisdiction which would shortly introduce the most determined program of indeterminate sentencing in Australia, the report drafted by Victoria's Police Commissioner was strangely out of step, in part through the prejudice of a mind that saw only police and prisons officers as experts in crime. The conference, it was reported, had also considered indeterminate sentences as a means of dealing with habitual offenders but rejected this solution because of 'difficulties in the way of finding persons other than Prison or Police officials who could fairly and efficiently determine ... the proper duration of imprisonment to be served in each case' ${ }^{59}$ The section on habitual criminals proved to be the longest and most provocative of the final report, prompting even the more adventurous Queensland commissioner Parry-Okeden into strong dissent. He could not see O’Callaghan's scheme getting legislative backing and he could not agree 'with several of the arguments used ... as to destruction of hope by indeterminate sentences. ${ }^{90}$

One other social policy issue dealt with was prostitution. The focus was understandable in the context of the day. Late nineteenth century social reform movements and early twentieth century feminism both highlighted the 'social evil', in Australia as much as in Britain or the United States, as a perennial challenge to good government. ${ }^{61}$ The commissioners’ discussion reflected other kinds of concerns, acknowledging that 'in every State of the Commonwealth, prostitutes have their dwelling places amongst those of the respectable community'. Their solution was control rather

\footnotetext{
${ }^{58}$ Report, p.8

${ }^{59}$ Report, p.14

${ }^{60}$ W Parry-Okeden to T O’Callaghan, [Feb 1904], VPRS 3992 1903, VPRO

${ }^{61}$ Judith Allen, Sex \& Secrets: Crimes Involving Australian Women since 1880 (Melbourne, 1990); Alison Bashford, Imperial Hygiene: A Critical History of Colonialism, Nationalism and Public Health. (Houndsmills, UK; New York, 2004); Raelene Frances, Selling Sex : a Hidden History of Prostitution (Sydney, 2007)
} 
than eradication, evident in their resolution 'that it is desirable to introduce legislation providing for the concentration of brothels'. This was a controversial policy option, as the commissioners conceded: in some quarters 'this recognition of the social evil [of prostitution]' would be taken as a form of 'legalising prostitution’. The police commissioners’ consideration stood firmly and safely in the middle of later Victorian approaches, highlighting the medical threats of unregulated prostitution. The conference felt 'that much evil results from the lack of medical supervision' of prostitutes. In seeking to counter contagious (venereal) disease associated with prostitution, the conference supported the medical supervision of prostitutes and resolved that 'the introduction of a system of compulsory medical examination would ... do much to stamp out a disease dangerous to the community. ${ }^{62}$ When it came to social policy it seemed that there was as much disagreement within the ranks of police commissioners as in the general community. Queensland's Commissioner Parry-Okeden, commenting on the suggestion that legislation provide 'for the concentration of brothels', wrote that concentration 'would be strongly and probably successfully opposed by property owners. ${ }^{63}$ By the time the draft report was circulated Thomas Garvin was now Acting Inspector-General of Police in New South Wales. He expressed strong dissent from the recommendations on prostitution: 'I am utterly in opposition to the proposal, as it is tantamount to legalising the existence of Brothels ..., but I am strongly in favour of the establishment of a free Lock Hospital. ${ }^{, 64}$ In their focus on this issue the police commissioners in 1903 were also highlighting the challenge posed to policing by ambiguous social and criminal justice policy

\footnotetext{
${ }^{62}$ Report, p.6

${ }^{63}$ W Parry-Okeden to T O’Callaghan, [Feb 1904], VPRS 3992 1903, VPRO

${ }^{64}$ T Garvin to T O’Callaghan, 25 Jan 1904, VPRS 3992 1903, VPRO
} 
approaches governing the work of police. The regulation of prostitution was to continue through most of the twentieth century as one of the most corrupting influences in Australian policing. ${ }^{65}$

Organisational matters did not preoccupy the commissioners in the degree that became common in later decades. An exception was their attention to exchange of personnel. Prior to the conference a number of the commissioners had expressed an interest in opportunities being provided for the exchange of police personnel between States, particularly detectives. In discussion the commissioners embraced the idea, affirming that exchanges provided 'members of the Force of each State an opportunity of becoming acquainted with the criminals of other States ...' The visiting police would 'remain three weeks to a month in the State visited'. The direction of the discussion makes clear the limits of what was expected from such an initiative. This was not so much an opportunity for learning, as a quite instrumental orientation to information gathering. By the 1920s if not earlier, exchange of officers was standard practice for a number of contiguous States, the value being generally measured against the expectation that visiting detectives would gather intelligence about criminals and their associates. In addition, exchange of personnel for institutional learning also began at this time, for example for the purpose of training some officers in fingerprint operations. ${ }^{66}$

For O'Callaghan, presentation of the report to his own Government was delayed by more than two months as the document was passed in sequence for signature from State to State with some of the commissioners adding comments, corrections or dissenting statements. There is no indication that O’Callaghan's draft report was amended or issued in a different final form. The next conference of

\footnotetext{
${ }^{65}$ Mark Finnane, “The Fitzgerald Commission: Law, Politics and State Corruption in Queensland”, Australian Journal of Public Administration, Vol.47 (1988), pp.332-342; Barbara Sullivan, The Politics of Sex: Prostitution and Pornography in Australia Since 1945, (Cambridge; Melbourne, 1997)

${ }^{66}$ Report, pp.4-5; for exchange of personnel between Queensland and NSW for fingerprint training see A/44779 82M 1907-1959, QSA.
} 
the commissioners was held in February 1917. On that occasion the conference was not concerned with general issues of police administration but was the initiative of George Steward, Official Secretary to the Governor-General, addressing national security issues during the First World War. The Great War transformed the policing environment forever, producing a momentum for much greater national interest in policing and domestic security issues. The core role of the States in criminal justice administration was not threatened but the longer-term interest of the Federal Government in policing had been secured. After 1917, the following conference was held in February 1921, once again convened by the Victorian Chief Commissioner of Police. Thereafter the conferences continued annually, with the exception of the years of the Great Depression, for the remainder of the twentieth century and to the present.

\section{Conclusion}

In the most penetrating study of the historical conditions for police co-operation Deflem has emphasized the historical bureaucratisation of police as the critical element. He does so in the course of developing a less reductionist understanding of police institutions. ${ }^{67}$ At the same time he suggests that any sociological model of internationalization of police work must recognise that national interests remain paramount in shaping the possibility of police co-operation across borders. The depth of his historico-sociological model of international police co-operation enables us to understand better how long-standing is the phenomenon of internationalization of policing, and how inadequately understood if only by reference to a recent history of ‘globalisation’.

The historical study of police co-operation within as much as without nation-states is even less well advanced than that of international policing. This article has explored the origins of a formal

${ }^{67}$ Deflem, Policing World Society, pp.28-34 
exercise in co-operation at the turn of the twentieth century. The hiatus after the 1903 Conference of Australian Police Commissioners was likely a signal of the lack of substantial over-riding national interests, a lack that the experience of the First World War would change, as it did more generally the prospects for international policing. But the historical evidence suggests that the origins of the Conference, the formation of its agenda and the constraints on its development are very much shared with the conditions that were shaping international police co-operation. We suggest that these conditions, might be adapted to explain the very fact of the Conference, as well as the substance of its agenda, and the delay in its subsequent development as an institutional expression of police co-operation.

We note in the first place the importance of bureaucratisation in Australian colonial policing. As much as Australian police organisations were legally constituted as subject to the direction of the government of the day, the geographical extent of their jurisdictions and the relative autonomy of their administration made them into formidable organs of state by the turn of the nineteenth century. In this respect the 1903 conference was institutionally more potent than the almost contemporaneous foundation meeting of the Chief Constables Association of Canada (1905), a body that represented primarily and less than comprehensively the interests of municipal police departments. ${ }^{68}$ From these features emerged police leaders who were confident in putting forward to government their own ideas about criminal justice policy. This did not guarantee uptake of police prescriptions, but the bureaucratic strength of these organisations was notable. In their debates with each other and in the evidence of their communications with state functionaries beyond Australian borders (eg with the French authorities in New Caledonia) we see demonstrated the bureaucratic capacity that was the momentum behind the 1903 conference.

\footnotetext{
${ }^{68}$ As Marquis notes, the CCAC developed as a 'national professional forum' which articulated the concerns of municipal police in a decentralised policing system: Policing Canada’s Century, pp. 3-5, 54
} 
Second we would argue that just as nation-state interests commonly acted as a constraint on the independent action of police forces engaged in international or cross-border co-operation, so also the local jurisdiction (in this case State governments) exercised a similar constraint. Although there is not the space to explore the evidence for this here, the longer history of the conferences shows repeated attempts by the State police forces in these commissioner conferences to adopt innovative policy and practice, only to find local political conditions constraining them. ${ }^{69}$ In their local jurisdictions the State police commissioners had already attained the degree of bureaucratic autonomy that (in Deflem's argument) constituted a critical condition for the development of cooperation. The inter-State conference proceeded without needing anything much more than formal consent from the respective political masters in each jurisdiction. At the same time, the commissioners remained very conscious of the constitutional and political contexts that would enable or limit any measures to advance co-operation and exchange in policing, within the overall federal political framework.

Third, we can adapt another of Deflem's propositions - relating to the operational motivation, the shared commitment of police departments to fighting crime - to suggest why there was a hiatus after 1903 in this institutional mode of promoting police co-operation. The shared knowledge of changing technologies and policing practices in late nineteenth century policing helped shape the emergence of co-operation within as well as beyond nation-states. Thus, we know that the challenge of developing communicative systems to support finger printing and Bertillonage were critical factors in stimulating the proposal for the 1903 conference. Similarly these new technologies had prompted significant co-operation between the British and French empires, through their colonial outposts in the south-west Pacific, in tracking the movement of criminal and

\footnotetext{
${ }^{69}$ For an analysis of this tension in relation to the policing of immigrants see Mark Finnane, Controlling the 'alien' in mid-twentieth century Australia: the origins and fate of a policing role. Policing and Society 19, no. 4: 442-467
} 
ex-convicts. Paradoxically it may be that the very influence of these new technologies in shaping the conference initiative also contributed to the absence of further conferences before 1917. For after 1903 it is clear that police in the various jurisdictions were systematically collecting fingerprints, in conjunction with the prison authorities, and communicating as necessary with their inter-State counterparts. The administrative understandings reached in 1903 enabled interchange of personnel to help establish cross-border communications and finger-print systems that fulfilled the main purposes of any institutional co-operation agenda before the Great War. Beyond those limited purposes, which already stretched the boundaries of legal and constitutional arrangements in postfederation criminal jurisdiction, there was for the moment little desire for continuing the exercise. 